\title{
Mechanism of antimicrobial activity of honeybee (Apis mellifera) venom on Gram-negative bacteria: Escherichia coli and Pseudomonas spp.
}

\author{
Izlem Haktanir ${ }^{1^{*}} \mathbb{D}$, Maria Masoura' ${ }^{1}$ Fani Th Mantzouridou ${ }^{2}$ and Konstantinos Gkatzionis ${ }^{1,3 *}$
}

\begin{abstract}
Honeybee venom (Apitoxin, BV), a secretion substance expelled from the venom gland of bees, has being reported as antimicrobial against various bacterial species; however, the mechanism of action remains uncharacterized. In this study, the antibacterial activity of BV was investigated on hygiene indicator Escherichia coli and the environmental pathogen and spoilage bacterial species, Pseudomonas putida and Pseudomonas fluorescens. An array of methods was combined to elucidate the mode of action of BV. Viability by culture on media was combined with assessing cell injury with flow cytometry analysis. ATP depletion was monitored as an indicator to metabolic activity of cells, by varying BV concentration $(75,225$ and $500 \mu \mathrm{g} / \mathrm{mL})$, temperature $\left(25^{\circ} \mathrm{C}\right.$ and $\left.37^{\circ} \mathrm{C}\right)$, and time of exposure $(0$ to $24 \mathrm{~h})$. Venom presented moderate inhibitory effect on $E$. coli by viability assay, caused high membrane permeability and significant ATP loss where the effect was increased by increased concentration. The viability of $P$. putida was reduced to a greater extent than other tested bacteria at comparable venom concentrations and was dictated by exposure time. On the contrary, P. fluorescens appeared less affected by venom based on viability; however, flow cytometry and ATP analysis highlighted concentration- and time-dependent effect of venom. According to Transmission Electron Microscopy results, the deformation of the cell wall was evident for all species. This implies a common mechanism of action of the $B V$ which is as follows: the cell wall destruction, change of membrane permeability, leakage of cell contents, inactivation of metabolic activity and finally cell death.
\end{abstract}

Keywords: Apitoxin, Antimicrobial mechanism, Metabolic reduction, Membrane integrity, Cell morphology

\section{Key points}

- Application of BV antimicrobial activity on food spoilage bacterial species was observed.

- Effect of exposure time and BV concentration were driven by species.

- Bacterial cell wall and plasma membrane are putative targets of the BV.

\footnotetext{
*Correspondence: izlemhaktanir@gmail.com; k.gkatzionis@bham.ac.uk 1 School of Chemical Engineering, University of Birmingham, Edgbaston, Birmingham B15 2TT, UK

Full list of author information is available at the end of the article
}

\section{Springer Open}

(c) The Author(s) 2021. This article is licensed under a Creative Commons Attribution 4.0 International License, which permits use, sharing, adaptation, distribution and reproduction in any medium or format, as long as you give appropriate credit to the original author(s) and the source, provide a link to the Creative Commons licence, and indicate if changes were made. The images or other third party material in this article are included in the article's Creative Commons licence, unless indicated otherwise in a credit line to the material. If material is not included in the article's Creative Commons licence and your intended use is not permitted by statutory regulation or exceeds the permitted use, you will need to obtain permission directly from the copyright holder. To view a copy of this licence, visit http://creativeco mmons.org/licenses/by/4.0/. 


\section{Introduction}

Honeybee venom (BV, Apitoxin) is secreted from venom gland of worker honeybees and it is one of the products of apiculture among others such as honey, propolis, bee wax (Bogdanov 2017; Massaro et al. 2015). BV is a complex substance containing water $(88 \%)$ and a mixture of peptides, enzymes, amino acids and other components (Additional file 1: Table S1). BV is known to have been used in medicine in the treatment of various diseases, since the time of ancient civilisations (Ali 2012). Currently, BV immunotherapy products attained approval for marketing in many countries such as Bulgaria (Melivenon), Germany (Forapin), Slovakia (Virapin), Canada (Venex), New Zealand (Nectar Balm) (Kokot et al. 2011; $\mathrm{Li}$ et al. 2013). Likewise, there is ongoing research on medical applications of BV for asthma, arthritis, Parkinson's disease, Alzheimer's disease (Ali 2012; Socarras et al. 2017; Fratini et al. 2017) and treatment of human cancer cells (Hu et al. 2006; Ip et al. 2012; Jo et al. 2012; Jang et al. 2003; Liu et al. 2013). Despite concerns related to allergenicity and biogenic amine content (Additional file 1: Table S1), there are commercially available products for antiwrinkle facial treatment formulated with BV (e.g., Apiven (France), Manuka Doctor (New Zealand), Rodial (UK)). Although BV biological activity has attracted interest in medical and cosmetic applications, use in food is considerably less than other bee-products such as honey, bee pollen and propolis and was limited to use as a nutrient ingredient, for example in honey. Concerning previous studies, BV presents the potential to act as a natural antimicrobial in food applications.

One of the well evidenced properties of BV and its main components is its antimicrobial activity against bacteria, fungi (Perumal Samy et al. 2007; Al-Ani et al. 2015; Memariani and Memariani 2020), parasites (Adade et al. 2013), and viruses (Uddin et al. 2016). The reported antimicrobial activities of venom and its main components (i.e., melittin and Phospholipase $\mathrm{A}_{2}\left(\mathrm{PLA}_{2}\right)$ ) against bacterial strains were comprehensively reviewed as part of this study and are listed in Additional file 1: Table S2. Studies have demonstrated the antimicrobial activity of BV against both Gram-positive and Gram-negative species. The Minimum Inhibitory Concentration (MIC) for Gram positive strains ranges from $200 \mu \mathrm{g} / \mathrm{mL}$ to $8 \mu \mathrm{g} /$ $\mathrm{mL}$ for the most sensitive species Bacillus subtilis (AlAni 2015; Zolfagharian et al. 2016). On the other hand, Gram negative bacterial species appear more resistant to BV (MIC 60 to $>500 \mu \mathrm{g} / \mathrm{mL}$ ) (Al-Ani et al. 2015). Leandro et al. (2015) compared BV antimicrobial activity to melittin and $\mathrm{PLA}_{2}$ against oral pathogens Streptococcus salivarius, S. sobrinus, S. mutans, S. mitis, S. sanguinis, Lactobacillus casei, and Enterococcus faecalis by the concentration up to $400 \mu \mathrm{g} / \mathrm{mL}$ : the activity of melittin presented twice the activity of BV against tested bacteria (4 to $40 \mu \mathrm{g} / \mathrm{mL}$ ) while PLA ${ }_{2}$ was effective against only $L$. casei at $>400 \mu \mathrm{g} / \mathrm{mL}$. No synergistic activity of $\mathrm{PLA}_{2}$ and melittin was observed. Similarly, antimicrobial activity of melittin was found against Streptococcal and Staphylococcal strains including methicillin-resistant $S$. aureus (MRSA) strains, while PLA $_{2}$ did not exhibit any effect or synergetic activity on the cell viability (Choi et al. 2015). Recently, the synergetic activity of melittin and low power ultrasonication has been proposed as more inhibitory against Listeria monocytogenes compared to that for each antimicrobial agent separately (Wu and Narsimhan 2017). To the best of our knowledge, from the mechanistic point of view, $\mathrm{PLA}_{2}$ hydrolyses phospholipids at low rate for prolonged periods, so indirectly disrupts the cell membrane of bacteria (Banks and Shipolini 1986). In addition, melittin, the major compound of BV, is known for being responsible for most of the antimicrobial, antiallergic, anti-inflammatory, and anti-cancer effects of BV (Hu et al. 2006; Dong et al. 2015; Woods et al. 2017; Lee et al. 2019) because of Antimicrobial peptides (AMPs) properties (Adade et al. 2013). As described in previous studies, melittin increases cell permeability and integrates into phospholipid bilayers in low concentrations, and forms pores in the cell membrane in high concentrations which causes the release of $\mathrm{Ca}^{2+}$ ions or breaks phospholipid groups (Fennell et al. 1968; Shipolini 1984; Adade et al. 2013; Wu et al. 2016; Socarras et al. 2017). However, the outer membrane of Gram-negative bacteria obstructs penetration of melittin into the cytoplasmic membrane (Shai 2002; Al-Ani et al. 2015).

Although, the composition and effectiveness of BV against several bacteria are well reported, the investigation of the associated mechanism of action is limited to the role of melittin. In this study, different methods were combined to elucidate the antimicrobial activity and mode of action of BV against the Gram-negative Escherichia coli and for the first time Pseudomonas putida and Pseudomonas fluorescens. The effect of BV was investigated by culture on media and was correlated with cell membrane damage by assessing cell injury with flow cytometry (FC) analysis. ATP depletion was monitored as an indicator to metabolic activity of cells and changes on the cell membrane were further analysed by transmission electron microscopy (TEM). Activity of BV on bacterial species was tested on stationary phase at different temperature $\left(25^{\circ} \mathrm{C}\right.$ and $37^{\circ} \mathrm{C}$ ) and time of exposure (0 to $24 \mathrm{~h})$.

\section{Materials and methods Materials and samples}

Two batches of commercial freeze-dried Apis mellifera BV samples obtained by electrostimulation were 
used in this study, namely "BV-1" (Henan-Senyuan Biological Technology Co Ltd, China) and "BV-2" (Citeq biologics, Netherlands). Melittin ( $\geq 85 \%$ purity) was purchased from Sigma-Aldrich (UK). Nutrient agar (Oxoid Ltd., CM003), Nutrient broth (Oxoid Ltd., CM0001) and Phosphate-buffered saline (PBS) were supplied by Fisher Scientific (United Kingdom). Culture medium Luria-Bertani (LB) broth (Miller, L3152) and two stains, bis-(1,3-dibutylbarbituric acid) trimethine oxonol $\left(\mathrm{DiBAC}_{4}(3)\right)$ and propidium iodide $(\mathrm{PI})$, were purchased from Sigma-Aldrich (UK). HPLC grade water and acetonitrile (ACN) were from Chem-Lab (Belgium). Trifluoroacetic acid (TFA) was from Acros organics (Belgium). All other common reagents were of the appropriate purity from various suppliers.

\section{Microbial cultures}

Three Gram-negative bacterial strains E. coli K-12, MG1655 (ATCC 47,076), P. putida (ATCC 700,008), and P. fluorescens (NCIMB 9046) were maintained on nutrient agar petri dishes at $4{ }^{\circ} \mathrm{C}$. Cultures were grown at $37^{\circ} \mathrm{C}$ for $E$. coli in LB broth and $P$. putida in Nutrient broth, and at $25{ }^{\circ} \mathrm{C}$ for $P$. fluorescens in nutrient broth for $24 \mathrm{~h}$ shaking at $150 \mathrm{rpm}$. Cell cultivation yielded mid-stationary phase population of E. coli, P. putida and P. fluorescens with a concentration of approximately $10^{8} \mathrm{CFU}$ (Colony Forming Units)/mL. After centrifugation (11 $200 \mathrm{x} \mathrm{g}, 10 \mathrm{~min}$ ), cells were washed in Phosphate-buffered solution (PBS) twice and re-suspended in $1 \mathrm{~mL}$ of PBS before use in antimicrobial assays.

\section{Viability analysis by culture}

One milligram of each of the BV samples was used to prepare working solutions of 150,450 , and $1000 \mu \mathrm{g} / \mathrm{mL}$ in deionized water. For each strain, $100 \mu \mathrm{L}$ aliquots of cell suspension was mixed with $100 \mu \mathrm{L}$ of 150,450 and $1000 \mu \mathrm{g} / \mathrm{mL}$ of BV working solutions or deionized water (control) in 96-well plates and incubated for $24 \mathrm{~h}$ at $25^{\circ} \mathrm{C}$ and $37{ }^{\circ} \mathrm{C}$ shaking at $150 \mathrm{rpm}$. Bacterial viability was assessed at different time points of incubation $(0,4$ and $24 \mathrm{~h}$ ). Each sample was serially diluted in PBS buffer and plated on nutrient agar plates using the Miles and Misra technique (Miles et al. 1938). Each dilution was plated on nutrient agar and incubated at $37^{\circ} \mathrm{C}$ for E. coli and $P$. putida, and at $25^{\circ} \mathrm{C}$ for $P$. fluorescens for $24 \mathrm{~h}$. Following, the viable bacterial counts $(\mathrm{CFU} / \mathrm{mL})$ were determined.

\section{Assessment of cell membrane integrity by $\mathrm{FC}$ analysis}

Treated bacterial cultures were stained by adding $4 \mu \mathrm{l} /$ $\mathrm{mL}$ of PI and $\operatorname{DiBAC}_{4}(3)$ and incubated in the dark for 5 min. Stained cultures were analysed using an Attune Nxt, Acoustic Focusing Cytometer (Thermo Fisher Scientific, Singapore). Cells were excited with a blue laser at $488 \mathrm{~nm}$, and the emitted fluorescence was detected through a $400 \mathrm{~nm}$ band-pass filter for both dyes. The trigger was set for the green fluorescence $(550 \mathrm{~nm})$ channel and data acquired on dot plot of forward-scatter versus side scatter. Volumetric counting had an experimentally determined quantification limit of 10,000 events. All samples were performed in triplicate and the data was analysed using the Invitrogen Attune Nxt Software (Version 2.7).

\section{Monitoring of cell metabolic activity by ATP analysis}

Based on the results of viability and FC, the applied concentration of 75 and $500 \mu \mathrm{g} / \mathrm{mL}$ BV at 0 and $24 \mathrm{~h}$ were considered for testing metabolic activity. BacTiter-Glo ${ }^{\mathrm{TM}}$ Microbial Cell Viability Assay (Promega, USA) and a CLARIOstar Luminometer (BMG Labtech, Germany) were used for the quantitation of the ATP present in bacterial cell culture. The changes in metabolic activity of treated cells were assessed based on the reduction of relative light unit (RLU) in relation to control cells. The BacTiter-Glo $^{\mathrm{TM}}$ Microbial Cell Viability Assay was prepared according to manufacturer guidelines. A $100 \mu \mathrm{L}$ aliquot from each treated-cell culture was mixed with an equal volume of BacTiter-Glo ${ }^{\mathrm{TM}}$ reagent in triplicate and incubated for $5 \mathrm{~min}$ at $150 \mathrm{rpm}$ shaking. After incubation, the luminescence of samples was immediately measured with a Luminometer and analysed using MARS data analysis software.

\section{TEM analysis of microbial cells treated with BV.}

The changes of bacterial cell structure after BV treatment were observed with a JEOL 1400 transmission electron microscope with Morada Soft Imaging system. For each strain, cell suspension was prepared (Sect. 2.2), mixed with $1000 \mu \mathrm{g} / \mathrm{mL}$ of $\mathrm{BV}$ solutions or deionized water (control) in $1 \mathrm{~mL}$ microcentrifuge tube (1:1) and incubated for $24 \mathrm{~h}$ at $25{ }^{\circ} \mathrm{C}$, shaking at $150 \mathrm{rpm}$. Following, bacterial cells were centrifuged at $1372 \times g$ for $10 \mathrm{~min}$. The supernatant was discarded, and the pellet was washed twice by re-suspension in PBS followed by centrifugation. The cells were then fixed by suspending the pellet in $2.5 \%$ glutaraldehyde (in $0.1 \mathrm{M}$ phosphate buffer, $\mathrm{pH}$ 7.4) and stored at $4{ }^{\circ} \mathrm{C}$ for $1 \mathrm{~h}$. After primary fixation, the samples were washed with PBS. Cells were post-fixed with $1 \%$ osmium tetroxide for $1 \mathrm{~h}$ and washed briefly with distilled water. The post-fixed specimens were dehydrated in a graded ethanol series (twice in 50, 70, 90, 100\%, 100\% dried Alcohol for 15 min each). The specimens were further treated with propylene oxide twice each for $15 \mathrm{~min}$ as a transitional fluid and then embedded in resin. The polymerisation of the resin to form specimen blocks was accomplished in an oven at $60{ }^{\circ} \mathrm{C}$ for $16 \mathrm{~h}$. Ultrathin sections were cut with a diamond knife using an 
ultramicrotome and then mounted on bare copper grids. They were stained with $2 \%$ uranyl acetate and lead citrate, followed by examination with the electron microscope.

\section{RP-HPLC analysis of melittin}

BV-1 and BV-2 dry samples were suitably diluted in HPLC-grade water. The resulting aqueous solutions $(150 \mu \mathrm{g} / \mathrm{mL})$ were filtered through a $0.45 \mu \mathrm{m}$ PTFE filter (Waters, Milford, MA) before RP-HPLC analysis conducted as described by Rybak-Chmieleska and Szczesna (2004). The HPLC system was equipped with a LC-20AD pump (Shimadzu, Kyoto, Japan) and a SPD10AV UV-VIS detector (Shimadzu). Separation was achieved on a chromatographic column C18 (L x I.D., $250 \mathrm{~mm} \times 4.6 \mathrm{~mm}, 5 \mu \mathrm{m}$ particle size) (BioBasic, Thermo Scientific, UK). The elution system was consisted of $0.1 \%$ TFA in water (Solvent A) and 0.1\% TFA in the solution of ACN: water (80:20) (Solvent B). The linear gradient elution for solvent B was $5 \%-80 \%$ (40 min). The flow rate was $1 \mathrm{ml} / \mathrm{min}\left(25^{\circ} \mathrm{C}\right)$ and the injection volume $20 \mu \mathrm{L}$. Peak identification was based on standard available, relative retention time and literature. Quantification of melittin $(\mu \mathrm{g} / \mathrm{mL})$ was performed using external calibration curve $(220 \mathrm{~nm})$ and calculated by linear regression analysis.

\section{Statistical analysis}

All measurements and treatments were performed in triplicate $(\mathrm{N}=3)$. Statistical comparisons of the mean values carried out by one-way ANOVA, followed by Student's t-test using the SPSS 20.0 software (SPSS Inc., Chicago, IL). Results were considered statistically significant at $p<0.05$.

\section{Results}

\section{Effect of BV on viability of the bacteria}

The effects of samples BV- 1 and BV-2 on cells were comparable (Figs. 1, 2). The effect of BV on E. coli cells varied based on the conditions of treatment. E. coli treated with BV- 1 at $25^{\circ} \mathrm{C}$ presented a decrease in viability. This was less affected by increase in BV concentration for BV-2. Variation between BV samples can be explained by qualitative and quantitative differences in composition recorded by HPLC profiles of aqueous solutions of BV-1 and BV-2 $(150 \mu \mathrm{g} / \mathrm{mL})$ at $220 \mathrm{~nm}$ (Additional file 1: Figure S1), For example, the 1.3-fold higher concentration of melittin in solution of BV-2 compared with that in solution of BV-1 (62 vs $47.5 \mu \mathrm{g} / \mathrm{mL}$ ) could greatly affect their bactericidal activity.

Significant inhibition was observed when treating the cells with high concentration of BV $(500 \mu \mathrm{g} / \mathrm{mL})$ and for extended time (24 h) (Figs. 1, 2). P. putida was significantly affected by exposure time to BV regardless of temperature. The viability decreased proportionally to the increase of BV concentration $(p<0.05)$. However, 225 and $500 \mu \mathrm{g} / \mathrm{mL}$ of BV did not differ significantly in effect after $4 \mathrm{~h}$ of exposure for both samples (Figs. 1,2), suggesting adaptation of treated $P$. putida cells. In contrast, P. fluorescens appeared to be unaffected by BV regardless of concentration and exposure time or temperature.

\section{Effect of BV on bacterial membrane integrity}

FC analysis was employed to study bacterial injury in response to BV treatment. For treated bacteria, the percentage of PI-positive cells was significantly greater at all time points $(0,4$ and $24 \mathrm{~h})$ than the untreated cells at $25^{\circ} \mathrm{C}$ and $37^{\circ} \mathrm{C}(p<0.05)$ (Figs. 3, 4). Despite no evidence of detrimental decrease in cell viability in analysis by culture, for same conditions of treatment, E. coli presented significant increase of PI-positive cells percentage, especially for the case of BV-2 (Fig. 4), suggesting bactericidal effect at time zero. Following $4 \mathrm{~h}$ of BV treatment at 75 and $225 \mu \mathrm{g} / \mathrm{mL}, \operatorname{DiBAC}_{4}(3)$-positive cells significantly increased by $70 \%$, representing suspended injury of $E$. coli treated cells; however, increasing BV concentration to $1000 \mu \mathrm{g} / \mathrm{mL}$ did not increase further the number of $\operatorname{DiBAC}_{4}(3)$-positive cells (Figs. 3, 4).

Aligned with the responses observed in viability tests, P. putida cell membrane was significantly damaged by exposure time. BV-1 presented a significant increase in percentage of PI-positive cells compared to untreated at $37{ }^{\circ} \mathrm{C}$, whereas the number of $\mathrm{DiBAC}_{4}(3)$-positive cells were over $50 \%$ at $25{ }^{\circ} \mathrm{C}$ at time zero. However, $\mathrm{DiBAC}_{4}(3)$-positive cells significantly increased over $24 \mathrm{~h}$ regardless of temperature (Fig. 3). The PI-positive cells increased proportionally to the increase in BV-2 concentration at time zero, whereas $\mathrm{DiBAC}_{4}(3)$-positive cells increased over $24-\mathrm{h}$, except for treated cells at $500 \mu \mathrm{g} / \mathrm{mL}$ (Fig. 4).

P. fluorescens viability by culture seemed to be unaffected by BV regardless of concentration, exposure time or temperature; however, the $\mathrm{DiBAC}_{4}(3)$ positive cells (Fig. 3) and PI-positive cells (Fig. 4) were initially observed for $500 \mu \mathrm{g} / \mathrm{mL}$. Following $24 \mathrm{~h}$ of BV treatment, injury of cells and damage of membrane were increased proportionally to the increase in BV concentration.

\section{Effect of BV treatment on metabolic activity}

ATP-depletion in treated cells showed a strong effect of BV on metabolic activity. The ATP level of E. coli was significantly reduced (33\%) when treated with $500 \mu \mathrm{g} / \mathrm{mL}$ BV and around $30 \%$ at 24-h (Table 1). Similarly, treated cells of $P$. putida presented significant ATP reduction during incubation. The percentage of metabolically active cells was less than $10 \%$ following 24 -h BV treatment. In 

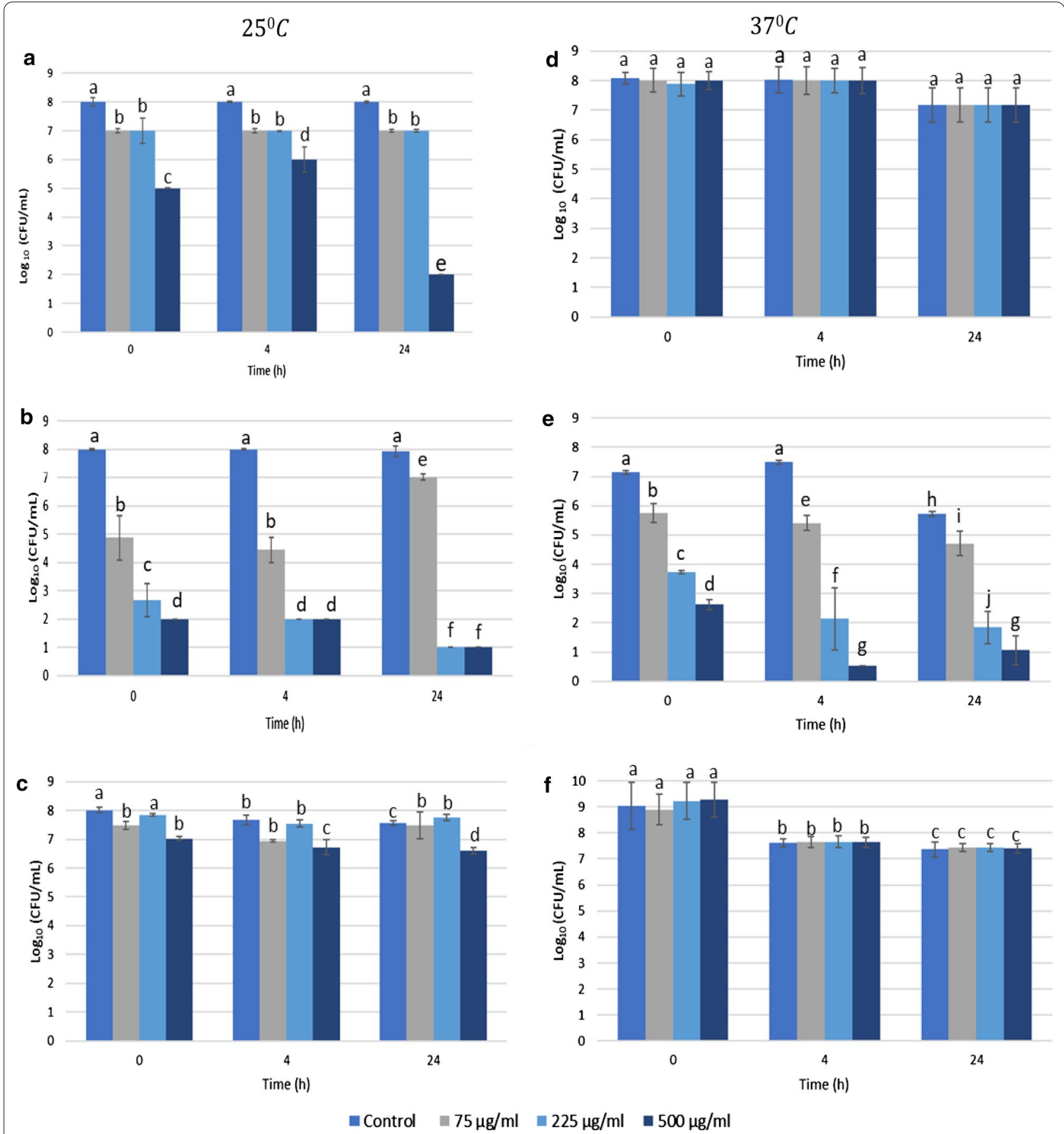

Fig. 1 Viability (CFU/mL) of a, d E. coli MG1655, b, e P. putida ATCC 700,008 and c, f P. fluorescens NCIMB 9046 incubated with BV-1 for 0, 4 and $24 \mathrm{~h}$ at $25^{\circ} \mathrm{C}$ (Left) and $37^{\circ} \mathrm{C}$ (Right). Error bars represent the standard deviation (sd) of the mean value ( $\mathrm{N}=3$ )

the case of $P$. fluorescens, ATP in treated cells presented a reduction by $20 \%$ with $500 \mu \mathrm{g} / \mathrm{mL}$.

\section{Analysis of cell morphological changes}

TEM was employed in order to visualise possible morphological changes in the wall and internal structure of bacterial cells. In the absence of BV, the bacterial cell membrane appeared intact with high-density cytoplasm for all species (Fig. 5). Upon exposure of E. coli cells to BV for $24 \mathrm{~h}$, membrane disruption was observed, and the leaked cytoplasmic material was found to be formed around the membrane. P. putida cell wall and the 

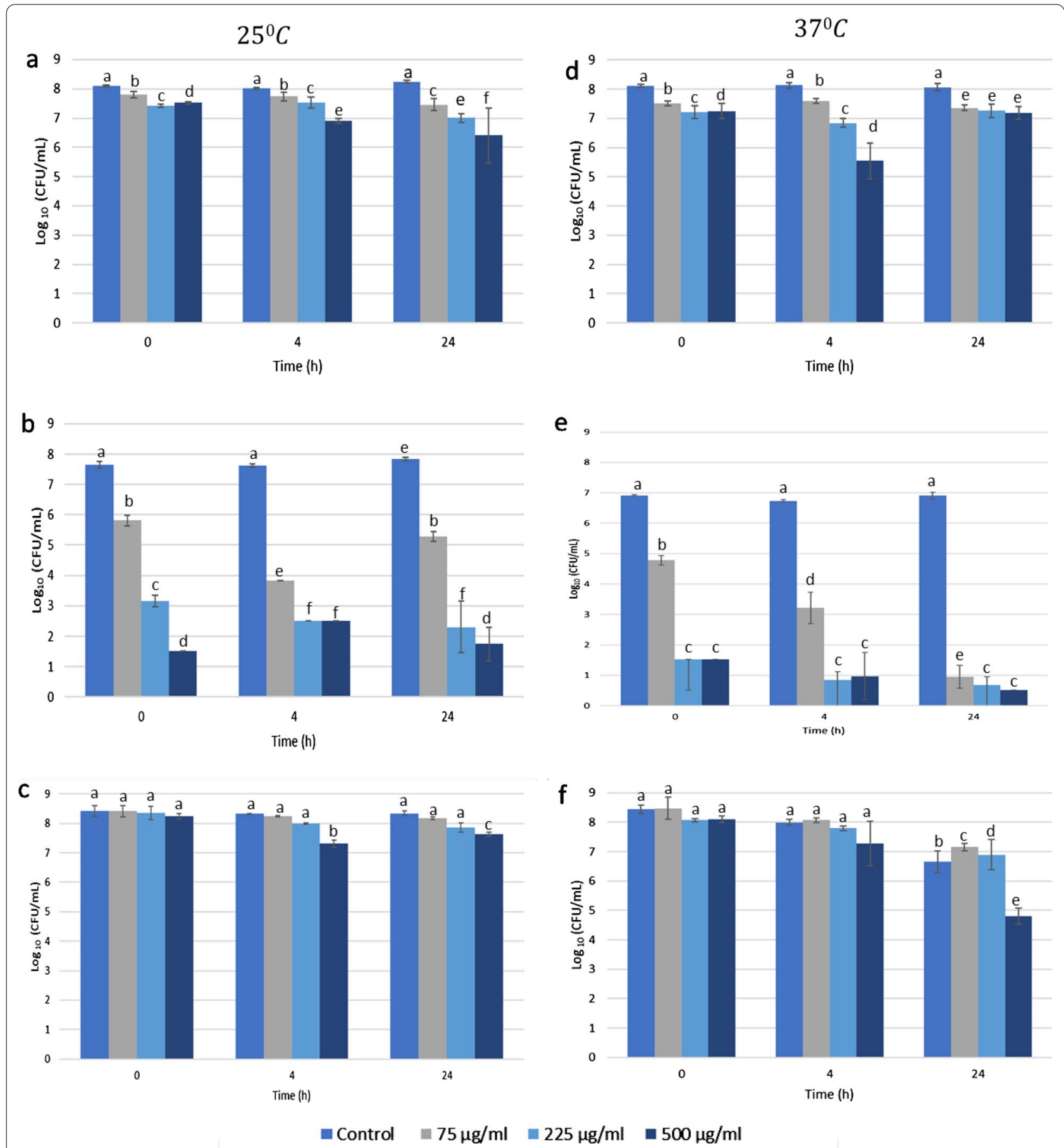

Fig. 2 Viability (CFU/mL) of a, d E. coli, MG 1655, b, e P. putida, ATCC 700,008 and c, f $P$. fluorescens, NCIMB 9046 in CFU/mL incubated with BV-2 for 0, 4 and $24 \mathrm{~h}$ at $25^{\circ} \mathrm{C}$ (Left) and $37^{\circ} \mathrm{C}$ (Right). Error bars represent the standard deviation (sd) of the mean value $(\mathrm{N}=3)$

cytoplasmic membrane showed uneven envelope, lysis of membrane integrity and leakage of intracellular contents, resulting in cytoplasmic vacuolation. The phospholipid bilayer of $P$. fluorescens cells was seriously deformed and the cell membrane was heavily damaged resulting to cytoplasmic leakage. Unlike other species, there were cells displaying intact structures and high-density of cytoplasm. 


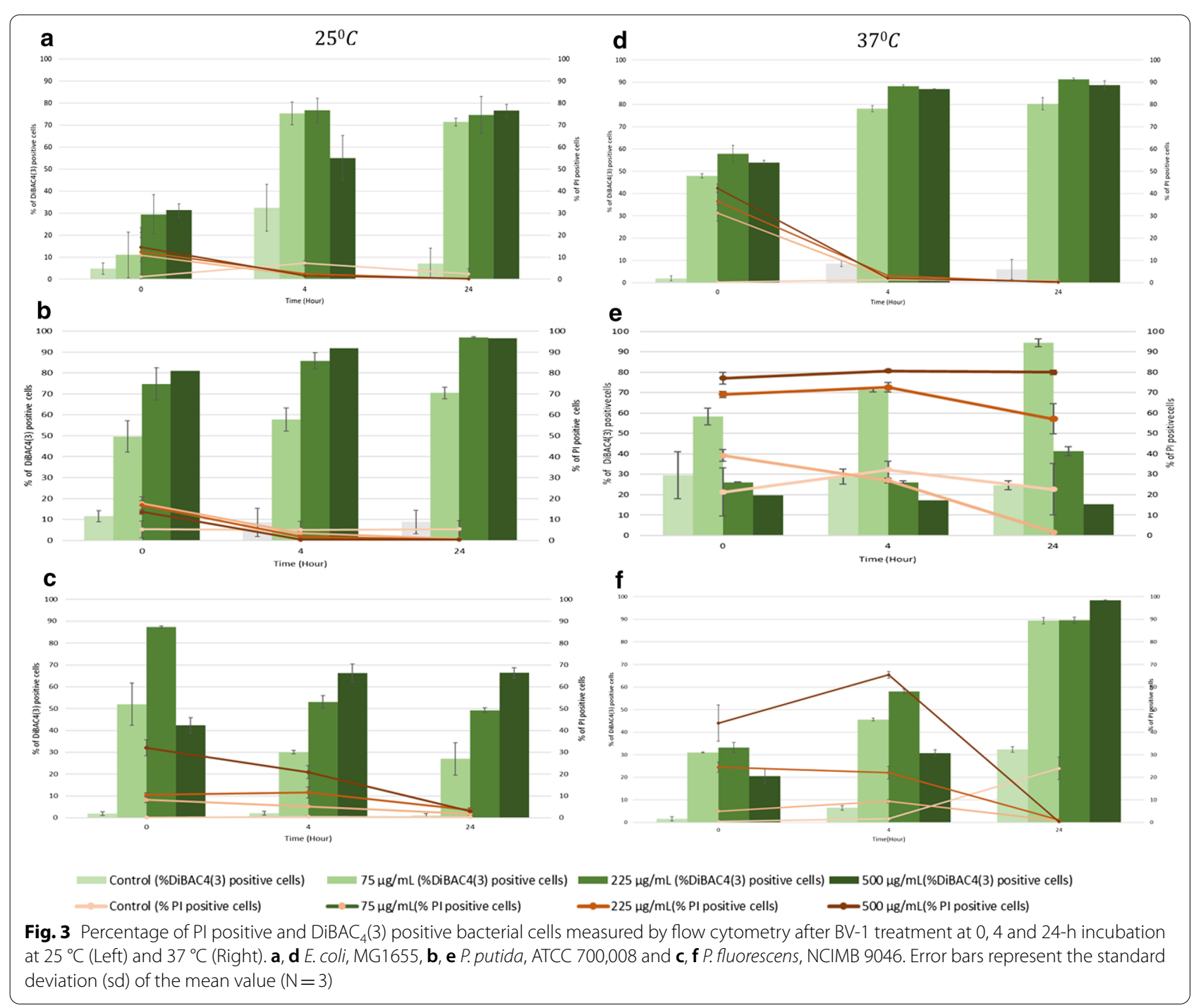

\section{Discussion}

BV has been shown to exert potent activity in microorganism against tested Gram-negative bacteria. Moreover, it was demonstrated that BV will be more effective if it is delivered in a manner that ensures optimum conditions of time and concentration. In this study, the variation in the number of viable cells treated with BV was found to be primarily driven by bacterial species. E. coli, $P$. fluorescens and P. putida presented different patterns in reduction of viability, for the same concentrations of BV. Therefore, these findings are consistent with previous reports, the activity of BV against E. coli between $100 \mu \mathrm{g} /$ $\mathrm{mL}$ and $500 \mu \mathrm{g} / \mathrm{mL}$ (Al-Ani et al. 2015) while $1800 \mu \mathrm{g} / \mathrm{mL}$ of BV was found the minimum concentration for inhibition (Hegazi et al. 2017). The effect of BV on P. putida and $P$. fluorescens have been studied for the first time in this study, hence, comparison of results is not available.
Surendra et al. (2011) has previously reported the antimicrobial activity of BV against $P$. aeruginosa to be concentration dependent, and the MIC was found $2400 \mu \mathrm{g} / \mathrm{mL}$ by Hegazi et al. (2017). Similarly, the bacteriostatic activity of BV against $P$. fluorescens and $P$. aeruginosa (Al-Ani et al. 2015) was found $500 \mu \mathrm{g} / \mathrm{mL}$. Moreover, the viability of $P$. putida was concluded in this study as most sensitive bacteria against $\mathrm{BV}$ at tested concentrations, followed by E. coli and P. fluorescens, suggesting, regardless of genera, species dependent BV activity which was also concluded in Choi et al. (2015).

In many cases of antibacterial agents, the target was the cell membrane, which is crucial for maintaining growth/ survival by isolating the intracellular material and energy balance. Hence, the effectiveness of a preservative is related to the damage to the cell membrane structure and disturbance of the function of enzyme system for the growth inhibition of bacteria (Yao 2012). It seems that 

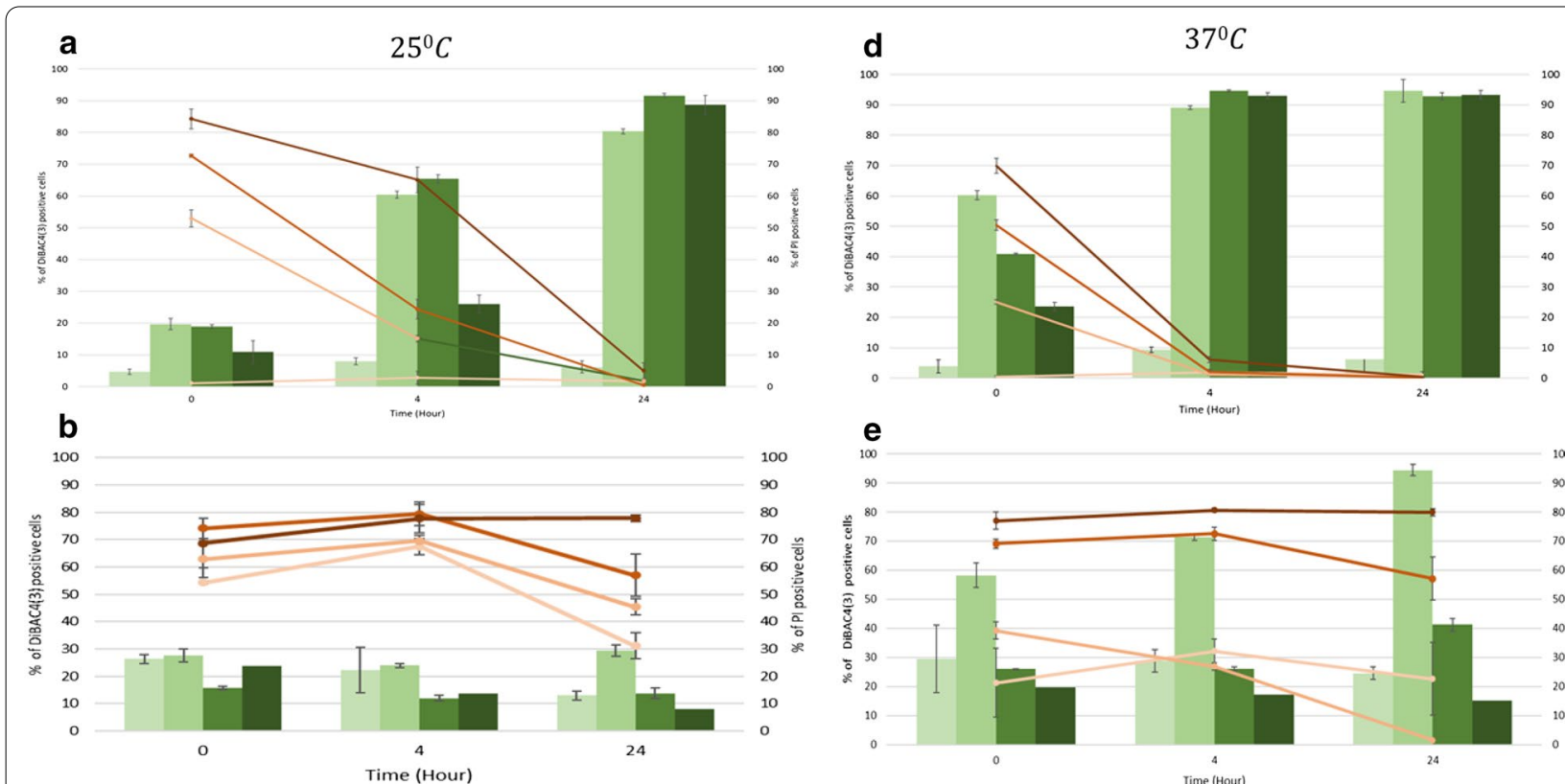

C
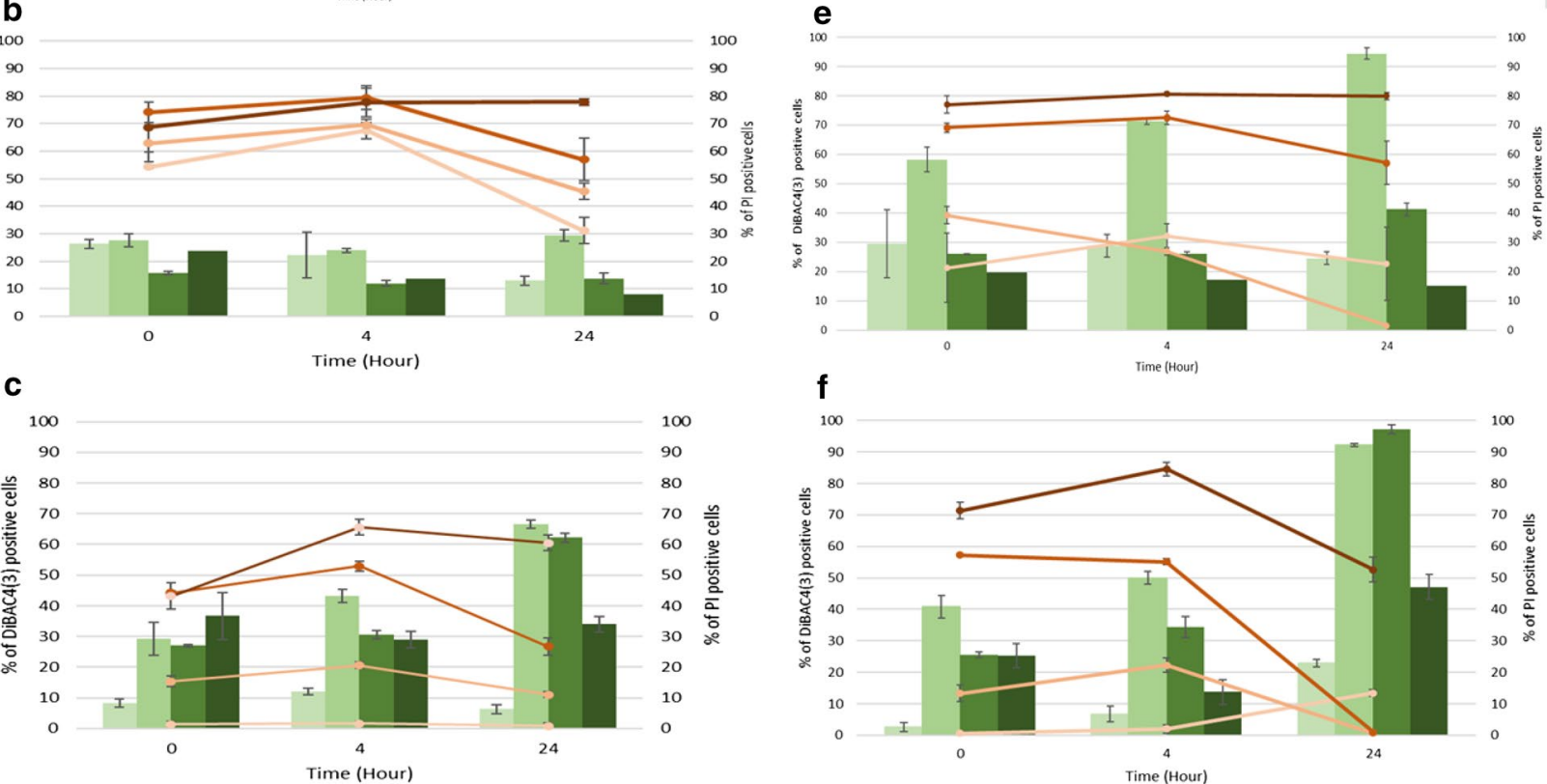

Control (\%DiBAC4(3) positive cells)

$75 \mu \mathrm{g} / \mathrm{mL}$ (\%DiBAC4(3) positive cells)

$225 \mu \mathrm{g} / \mathrm{mL}$ (\%DiBAC4(3) positive cells) $\longrightarrow 225 \mu \mathrm{g} / \mathrm{mL}$ (\% PI positive cells) $\longrightarrow 500 \mu \mathrm{g} / \mathrm{mL}$ (\% PI positive cells)

Fig. 4 Percentage of PI positive and $\mathrm{DiBAC}_{4}(3)$ positive bacterial cells measured by flow cytometry after BV-2 treatment at 0, 4 and 24-h incubation at $25^{\circ} \mathrm{C}$ (Left) and $37^{\circ} \mathrm{C}$ (Right). a, d E. coli, MG1655, b, e P. putida, ATCC 700,008 and c, f P. fluorescens, NCIMB 9046. Error bars represent the standard deviation (sd) of the mean value $(\mathrm{N}=3)$

Table 1 Percentage of metabolically active cells after bee venom treatment at 0 and $24-h$ at $25^{\circ} \mathrm{C}$

\begin{tabular}{|c|c|c|c|c|c|c|c|c|}
\hline \multirow[t]{2}{*}{ Time (hour) } & \multicolumn{4}{|l|}{ BV-1 } & \multicolumn{4}{|l|}{ BV-2 } \\
\hline & $\mathrm{Oh}$ & & $24 \mathrm{~h}$ & & $\mathrm{Oh}$ & & $24 \mathrm{~h}$ & \\
\hline Bacterial species & $75 \mu \mathrm{g} / \mathrm{mL}$ & $500 \mu \mathrm{g} / \mathrm{mL}$ & $75 \mu \mathrm{g} / \mathrm{mL}$ & $500 \mu \mathrm{g} / \mathrm{mL}$ & $75 \mu \mathrm{g} / \mathrm{mL}$ & $500 \mu \mathrm{g} / \mathrm{mL}$ & $75 \mu \mathrm{g} / \mathrm{mL}$ & $500 \mu \mathrm{g} / \mathrm{mL}$ \\
\hline E. coli & 100 & 33 & 29 & 20 & 85 & 36 & 28 & 28 \\
\hline P.putida & 100 & 100 & 78 & 43 & 100 & 100 & 12 & 2 \\
\hline P. fluorescens & 115 & 128 & 99 & 27 & 138 & 127 & 85 & 12 \\
\hline
\end{tabular}

BV affects membrane integrity and the plasma membrane potential of E. coli cells in association to significant loss of viability. In addition, the adaptation of treated P. putida cells was observed at $75 \mu \mathrm{g} / \mathrm{mL}$ BV over $24 \mathrm{~h}$. Therefore, the lethal effect of BV appeared to depend on exposure time above $75 \mu \mathrm{g} / \mathrm{mL}$. P. fluorescens distinctly presented sublethal stress behaviour, resulting injury and less metabolic activity at $24 \mathrm{~h}$.

The formation of pores and their size is acknowledged as crucial for the bacterial recovery death. Previous 

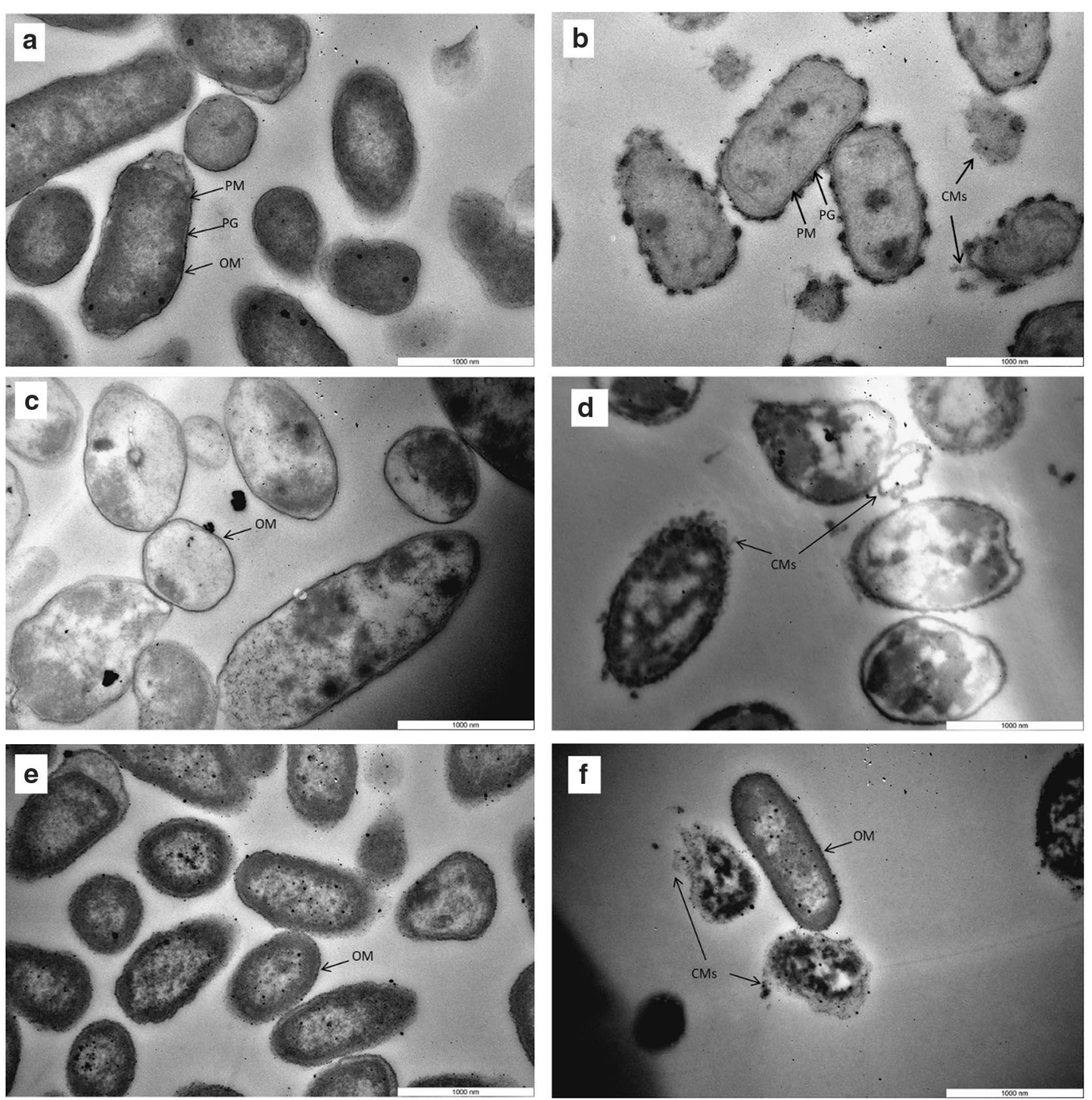

Fig. 5 Morphological changes of E. coli strain, MG1655, control (a) and treated (b), P. putida strain, ATCC 700,008 control (c) and treated (d), P. fluorescens strain, NCIMB 9046 control (e) and treated (f) after $24-\mathrm{h} \mathrm{BV}-2$ treatment ( $500 \mu \mathrm{g} / \mathrm{mL}$ at $25^{\circ} \mathrm{C}$ observed by TEM (magnification $50 \mathrm{~K}$ ). Control cells were prepared incubated with de-ionised water. OM outer membrane, $P G$ peptidoglycan layer, $P M$ plasma membrane, CMs cytoplasmic materials

studies on Gram positive cells suggested that the effect of BV on cell membrane permeability is associated to melittin by forming of pores on the cell wall, and a property of AMPs (Wu \& Narsimhan 2017). In a study conducted by Wu et al. (2016), the effect of melittin was observed by TEM comprised damage and pore formation in the cell membrane of Gram-positive $S$. aureus followed by increased cell permeabilization through the cytoplasmic membrane. However, the outer membrane of Gramnegative bacteria, which contains lipopolysaccharides (LPS), obstructs penetration of melittin into the cytoplasmic membrane (Shai 2002; Al-Ani et al. 2015). To the best of our knowledge, the second main compound,
$\mathrm{PLA}_{2}$, enzymatically hydrolyses phospholipids at low rate for prolonged periods which indirectly disrupts the cell membrane of Gram-negative bacteria (Banks and Shipolini 1986). Therefore, the antimicrobial mechanisms of action of melittin could not associated as the mechanism of BV on Gram negative bacterial cells.

The present study confirmed that cell wall and membrane disruptions increase membrane permeability. Following $24 \mathrm{~h} \mathrm{BV}$ treatment, the leaked cytoplasmic materials were found to be formed around all tested cells. The phospholipid bilayer of bacteria was deformed the cell membrane was heavily damaged and the shape of some cells became irregular. Cytoplasm was not evenly 
distributed, resulting in cytoplasmic vacuolation. Hence, the microbial cell growth was inhibited by BV. However, the observation of intact structure P. fluorescens cells also suggested the resistance against BV which is consistent with the results obtained from culture analysis, FC and ATP analysis. Although the complete mechanism of action of BV against bacteria has not been fully elucidated yet, together, the data of the present study demonstrated for the first time, to the best of our knowledge, BV may be used as a promising natural antimicrobial agent on Gram-negative species from pharmaceutical to food applications.

BV consists of a large number of peptides. Therefore, activity similar to AMPs could be expected in food matrices and processes, in terms of water solubility, thermostability, tolerance to high or low ionic strength and $\mathrm{pH}$ values. In this study, BV antimicrobial activity was investigated under the optimal temperatures $\left(25^{\circ} \mathrm{C}\right.$ and $37^{\circ} \mathrm{C}$ ) for the growth of the target microorganisms common in food applications under a range of low concentrations $(75,225$ and $500 \mu \mathrm{g} / \mathrm{mL})$. The results indicated that the activity of BV was evident in most tested conditions. Yet, BV has not been exploited as a natural food preservative at industrial scale, and research is rather limited. The challenge would be to ensure BV stability and activity in the presence of intrinsic food properties and environmental conditions that are known to affect bacterial growth and food safety. Studies in solid model systems have shown that food structure protects immobilized or surface attached cells due to the development of acid tolerance and susceptibility to inhibitory agents such as lactic acid or antimicrobial agents (Boons et al. 2013; Lobete et al. 2015; Noriega et al. 2010). Also, BV is considered a rich source of biogenic amines such as histamine (Barkiene et al. 2020; Official Journal of the European Union 2005), a fact that could limit its threshold in food applications.

\section{Supplementary Information}

The online version contains supplementary material available at https://doi. org/10.1186/s13568-021-01214-8.

Additional file 1: Table S1. Composition of dry honeybee venom, (Shipolini 1984; Pucca et al. 2019). Table S2. Summary of studies on antimicrobial activity of honeybee venom against bacteria. Figure $\mathbf{S 1}$. HPLC chromatograms of melittin standard aqueous solution $(50 \mathrm{\mu g} / \mathrm{mL})$ (a) BV-1 (b) and 45 BV-2 (c) aqueous solutions $(150 \mu \mathrm{g} / \mathrm{mL})$ at $220 \mathrm{~nm}$. Peak (*): melittin. Detection was at $220 \mathrm{~nm} 46$ (Chromatographic conditions as in Materials and Methods section).

\section{Acknowledgements}

This research has been funded by BBSRC, Midlands Integrative Biosciences Training Partnership (MIBTP) Doctoral Training Partnership.

\section{Authors' contributions}

$I H$ and KG conceived and designed the research. IH conducted experiments. $\mathrm{IH}, \mathrm{KG}, \mathrm{MM}$ and FM contributed analytical tools and analysed data.

\section{Funding}

This research has been funded by BBSRC, Midlands Integrative Biosciences Training Partnership (MIBTP) Doctoral Training Partnership.

\section{Availability of data and materials}

The data that support the findings of this study are available from the corresponding author upon reasonable request.

\section{Declarations}

\section{Ethics approval and consent to participate}

This article does not contain any studies with animals or human participants performed by any of the authors.

\section{Consent of publication}

Not applicable.

\section{Competing interests}

All authors declare that there is no competing interests.

\section{Author details}

'School of Chemical Engineering, University of Birmingham, Edgbaston, Birmingham B15 2TT, UK. ${ }^{2}$ Laboratory of Food Chemistry and Technology, Department of Chemistry, Aristotle University of Thessaloniki, 54124 ThessaIoniki, Greece. ${ }^{3}$ Department of Food Science and Nutrition, School of the Environment, University of the Aegean, Metropolite loakeim 2, 81400 Myrina, Lemnos, GR, Greece.

Received: 28 January 2021 Accepted: 29 March 2021

Published online: 09 April 2021

\section{References}

Adade CM, Oliveira IR, Pais JA, Souto-Padron T (2013) Melittin peptide kills Trypanosoma cruzi parasites by inducing different cell death pathways. Toxicon 69:227-239. https://doi.org/10.1016/j.toxicon.2013.03.011

Al-Ani I, Zimmermann S, Reichling J, Wink M (2015) Pharmacological synergism of bee venom and melittin with antibiotics and plant secondary metabolites against multi-drug resistant microbial pathogens. Phymed 22:245-255. https://doi.org/10.1016/j.phymed.2014.11.019

Ali M (2012) Studies on bee venom and its medical uses. IJOART 1:2

Banks BEC, Shipolini RA (1986) Chemistry and pharmacology of honey-bee venom. In: PiekT (ed) Venoms of the Hymenoptera. Academic press, London, pp 329-415

Barkiene E, Sakiene V, Zavistanaviute P, Zokaityte E, Dauksiene A, Jagminas P, Klupsaike D, Bliznikas S, Ruzauskas M (2020) Variations of theantimicrobial, antioxidant, sensory attributes and biogenic amines content in Lithuaniaderived bee products. LWT-Food Sci Technol 118:108793. https://doi.org/ 10.1016/j.lwt.2019.108793

Bogdanov S (2017) Bee Venom: composition, health, medicine: a review. Bee Science Product

Boons K, Mertens L, Van Derlinden E, David CC, Hofkens J, Van Impe JF (2013) Behavior of Escherichia coli in a heterogeneous gelatin-dextranmixture. Appl Environ Microbiol 79:3126-3128. https://doi.org/10.1128/AEM. 03782-12

Choi J, Jang A, Lin S, Lim S, Kim D, Park K, Han S, Yeo J, Seo H (2015) Melittin, a honeybee venom-derived antimicrobial peptide, may target methicillinresistant Staphylococcus aureus. Mol Med Rep 12(5):6483-6490. https:// doi.org/10.3892/mmr.2015.4275

Dong J, Ying B, Huang S, Ma S, Long P, Tu X, Yang W, Wu Z, Chen W, Miao X (2015) High-performance liquid chromatography combined with intrinsic fluorescence detection to analyse melittin in individual honeybee (Apis mellifera) venom sac. J Chromatogr B 1002:139-143. https://doi.org/10. 1016/j.jchromb.2015.08.014 
Fennell JF, Shipman WH, Cole LJ (1968) Antibacterial action of Melittin, polypeptide from bee venom. Proc Soc Exp Biol Med 127(3):707-710

Fratini F, Cilia G, Turchi B, Felicioli A (2017) Insects, arachnids, and centipedes' venom: a powerful weapon against bacteria A literature reviews. Toxicon 130:91-103. https://doi.org/10.1016/j.toxicon.2017.02.020

Hegazi AG, Abd-Allah FM, Saleh AA, Abdou AM, Fouad EA (2017) Antibacterial Activity of Italian (Apis mellifera) bees Venom. JCPS 10(3):1188-1192

Hu H, Chen D, Li Y, Zhang X (2006) Effect of polypeptides in bee venom on growth inhibition and apoptosis induction of the human hepatoma cell line SMMC-7721 in-vitro and Balb/c nude mice in-vivo. J Pharm Pharmacol 58(1):83-89

Ip SW, Chu YL, Yu CS, Chen PY, Ho HC, Yang JS, Huang HY, Chueh FS, Lai TY, Chung JG (2012) Bee venom induces apoptosis through intracellular Ca2+-modulated intrinsic death pathway in human bladder cancer cells. Int J Urol 19:61-70

Jang MH, Shin MC, Lim S, Han SM, Park HJ, Shin I, Lee JS, Kim KA, Kim EH, Kim CJ (2003) Bee venom induces apoptosis and inhibits expression of cyclooxygenase-2 mRNA in human lung cancer cell line NCl-H1299. J Pharmacol Sci 91(2):95-104

Jo M, Park MH, Kollipara PS, An BJ, Song HS, Han SB, Kim JH, Song MJ, Hong JT (2012) Anti-cancer effect of bee venom toxin and melittin in ovarian cancer cells through induction of death receptors and inhibition of JAK2/ STAT3 pathway. Toxicol Appl Pharmacol 258:72-81

Kokot ZJ, Matysiak J, Urbaniak B, Derezinski P (2011) New CZE-DAD method for honeybee venom analysis and standardization of the product. Anal Bioanal Chem 399:2487-2494. https://doi.org/10.1007/s00216-010-4627-2

Leandro L, Mendes C, Casemiro L, Vinholis A, Cunha W, Almeida R, Martins C (2015) Antimicrobial activity of apitoxin, melittin and phospholipase $A_{2}$ of honeybee (Apis mellifera) venom against oral pathogens. An Acad Bras Ciênc 87(1):147-155. https://doi.org/10.1590/0001-3765201520130511

Lee JE, Shah VK, Lee EJ, Oh MS, Choi JJ (2019) Melittin- A bee venom component - Enhances muscle regeneration factors expression in a mouse model of skeletal muscle contusion. J Pharmacol Sci 140:26-32. https:// doi.org/10.1016/j.jphs.2019.03.009

Li R, Zhang L, Fang Y, Han B, Lu X, Zhou T, Feng M, Li J (2013) Proteome and phosphoproteome analysis of honeybee (Apis mellifera) venom collected from electrical stimulation and manual extraction of the venom gland. BMC Genomics 14:766

Liu H, Han Y, Fu H, Liu M, Wu J, Chen X, Zhang S, Chen Y (2013) Construction and expression of STRAIL-melittin combining enhanced anticancer activity with antibacterial activity in Escherichia coli. Appl Microbiol and Biotechnol 97:2877-2884. https://doi.org/10.1007/s00253-012-4541-y

Lobete MM, Fernandez EN, Van Impe JFM (2015) Recent trends in non-invasive in situ techniques to monitor bacterial colonies in solid (model) food. Front Microbiol 6:148

Massaro C, Simpson J, Powell D, Brooks P (2015) Chemical composition and antimicrobial activity of honeybee (Apis mellifera ligustica) propolis from subtropical eastern Australia. Sci Nat 102:11-12

Memariani H, Memariani M (2020) Anti-fungal properties and mechanisms of melittin. Appl Microbiol and Biotechnol 104:6513-6526. https://doi.org/ 10.1007/s00253-020-10701-0

Miles AA, Misra SS, Irwin J (1938) The estimation of the bactericidal power of blood. J Hyg (Lond) 38:732

Noriega E, Laca A, Diaz M (2010) Decisive role of structure in food microbial colonization and implications for predictivemicrobiology. J Food Protect 73:938-951. https://doi.org/10.3389/fmicb.2015.00148
Official Journal of the European Union COMMISSION REGULATION (EC) No 2073/2005 of 15 November 2005 on microbiological criteria forfoodstuffs (2005), pp L 338/1-L 338/26

Perumal Samy R, Gopalakrishnakone P, Thwin MM, Chow TKV, Bow H, Yap EH, Thong TWJ (2007) Antibacterial activity of snake, scorpion and bee venoms: a comparison with purified venom phospholipase $A_{2}$ enzymes. J Appl Microbiol 102:650-659. https://doi.org/10.1111/j.1365-2672.2006. 03161.x

Pucca MB, Cerni FA, Oliveira IS, Jenkins TP, Argemí L, Sørensen CV, Ahmadi S, Barbosa JE, Laustsen AH (2019) Bee Updated: Current Knowledge on Bee Venom and Bee Envenoming Therapy. Front Immunol 10:2090. https:// doi.org/10.3389/fimmu.2019.02090

Rybak-Chmielewska H, Szczęsna T (2004) HPLC study of chemical composition of honeybee (Apis mellifera L.) venom. J Apic Sci 48:103-109

Shai $Y$ (2002) Mode of action of membrane active antimicrobial peptides. Biopolymers 66:236-248

Shipolini RA (1984) Biochemistry of Bee venom. In: Tu AT (ed) Insect Poisons, Allergens, and Other Invertebrate Venoms, vol 2. Marcel Dekker, New York, pp 49-85

Socarras KM, Theophilus PAS, Torres JP, Gupta K, Sapi E (2017) Antimicrobial activity of bee venom and melittin against Borrelia burgdorferi. Antibiotics 6(31). https://doi.org/10.3390/antibiotics6040031.

Surendra NS, Jayaram GN, Reddy MS (2011) Antimicrobial activity of crude venom extracts in honeybees (Apis cerana, Apis dorsata, Apis florea) tested against selected pathogens. African J Microbiol Res 5(18):2765-2772. https://doi.org/10.5897/Ajmr11.593

Uddin MB, Lee BH, Nikapitiya C, Kim JH, Kim TH, Lee HC, Kim CG, Lee JS, Kim CJ (2016) Inhibitory effects of bee venom and its components against viruses in vitro and in vivo. J Microbiol 54(12):853-866. https://doi.org/10. 1007/s12275-016-6376-1

Woods N, Niwasabutra K, Acevedo R, Igoli J, Altwaijry NA, Tusiimire J, Gray Al, Watson DG, Ferro VA (2017) Natural Vaccine Adjuvants and Immunopotentiators Derived from Plants, Fungi, Marine Organisms, and Insects. In: Schijns V, O'Hagan D (eds) Immunopotentiators in Modern Vaccines, 2nd edn. Academic Press, Cambridge, pp 211-229

Wu X, Narsimhan G (2017) Synergistic effect of low power ultrasonication on antimicrobial activity of melittin against Listeria monocytogenes. LWT 75:578-581. https://doi.org/10.1016/j.Iwt.2016.10.008

Wu X, Singh AK, Wu X, Lyu Y, Bhunia AK, Narsimhan G (2016) Characterization of antimicrobial activity against Listeria and cytotoxicity of native melittin and its mutant variants. Colloids Surf B Biointerfaces 143:194-205. https:// doi.org/10.3390/molecules21081084

Yao X, Zhu X, Pan S, Fang Y, Jiang F, Phillips GO, Xu X (2012) Antimicrobial activity of nobiletin and tangeretin against Pseudomonas.J J Food Chem 132:1883-1890. https://doi.org/10.1016/j.foodchem.2011.12.021

Zolfagharian H, Mohajeri M, Babaie M (2016) Bee venom (Apis Mellifera) an effective potential alternative to gentamicin for specific bacteria strains: Bee venom an effective potential for bacteria. J Pharmacopuncture 19:225-230. https://doi.org/10.3831/KPI.2016.19.023

\section{Publisher's Note}

Springer Nature remains neutral with regard to jurisdictional claims in published maps and institutional affiliations. 